\title{
CHOICE OF LATV GOVERNING LAND TRANSACTIONS: THE CONTRACT-CONVEYANCE DICHOTOMY
}

In choosing the law to govern multistate land transactions, most courts have held that a conveyance of an interest in land and all issues concerning title are governed by the law of the situs, ${ }^{1}$ whereas contracts to convey are governed by the choice-of-law rules normally applied to contract cases. ${ }^{2}$ Courts have thus sought to characterize a transaction as affecting either interests in land or the rights of parties inter se. However, the fact that many land transactions can fit comfortably into either characterization ${ }^{3}$ demonstrates the inadequacy of the contract-conveyance dichotomy as the sole choice-of-law rule.

There has been increasing recognition that transactions are properly regulated by the law of the state having the more significant contacts with them. ${ }^{*}$ By uncovering the purposes of conflicting local laws, it is usually possible to appraise the significance of various contacts and determine which state has the greatest interest in having its law applied. ${ }^{5}$ It is along these lines that courts should seek to replace the predominantly mechanistic application of the contract-conveyance dichotomy to land transactions. When diverse local laws vie for recognition in a given case, not only should the specific purposes of the conflicting rules be analyzed, but also consideration should be given to the reasons which originally led to the distinction between transactions affecting interests in land and those affecting rights of parties inter se. In particular, a state's interest in obtaining certainty and uniformity with respect to title to land situated

1 E.g. Wilson v. Kryger, 29 N.D. 28,149 N.W. 721 (1914), aff'd, 242 U.S. 171 (1916); Clark v. Graham, 19 U.S. (6 Wheat.) 577 (1821); United States v. Crosby, 11 U.S. (7 Cranch) 115 (1812). See generally Goodrich, Conflict of Laws $\$ 148$ (3d ed. 1949).

2 E.g., Liljedahl v. Glassgow, 190 Iowa 827,180 N.W. 870 (1921) ; Atwood v. Walker, 179 Mass. 514, 61 N.E. 58 (1901); Pólson v. Stewart, 167 Mass. 211, 45 N.E. 737 (1897); Walsh v. Selover, Bates \& Co., 109 Minn. 136, 123 N.W. 291 (1909), aff'd, 226 U.S. 112 (1912). See generally Gooprich, Cosfrlict of Laws $\S 149$ (3d ed. 1949); Leflar, CoNflict of Laws $\$ 144$ (1959).

${ }^{3}$ Compare Selover, Bates \& Co. v. Walsh, 226 U.S. 112 (1912), with Kryger v. Wilson, 242 U.S. 171 (1916). Compare Polson y. Stewart, supra note 2, avith Kyle v. Krle, 128 So. $2 d 427$ (Fla. Dist. Ct. App. 1961), appeal dismissed, 139 So. 2d 885 (1962). See p. 483 infra.

4 [D] etermining which contact is the most significant... requires the exercise of an informed judgment in the balancing of all the interests of the states with the most significant contacts in order best to accommodate the equities among the parties to the policies of those states.

Vanston Comm. v. Green, 329 U.S. 156, 161-62 (1946) ; see Fricke v. Isbrandtsen Co., 151 F. Supp. 465 (S.D.N.Y. 1957); Auten v. Auten, 308 N.Y. 155, 160-61, 124 N.E.2d 99 , 102 (1954). See generally Rfstatenent (SECOND), Conflict or Laws $\S 332$ (b) ('Tent. Draft No. 6, 1960).

5 See generally Currie, Notes on Methods and Objectives in the Conflict of Lazus, 1959 DUKE L.J. 171, 173-80. 
within it ${ }^{b}$ should be weighed against the interest of another state in regulating the activity of its residents or the performance of contracts within its borders. ${ }^{7}$ To lump indiscriminately such dissimilar issues as capacity to contract, applicability of a statute of frauds, and assumption of a mortgage into one category-contracts-is to disregard the differing state interests manifested in various local laws.

It is the purpose of this Note to underscore the inadequacy of the contract-conveyance dichotomy as a ubiquitous choice-of-law rule, to evaluate the departure from existing law propounded by the most recent draft of the Restatement of Conflict of Lazes, and to suggest an approach by which contacts and state interests, cast in the light of the purposes of local laws, may be weighed in concrete fact situations.

\section{Inadequacy of the Contract-Conveyance Dichotomy}

Too many land transactions can too easily be characterized as affecting both interests in land and rights of parties. In Polson v. Stewart, ${ }^{8}$ the case generally cited as establishing the contract-conveyance dichotomy, a husband contracted with his wife at their North Carolina domicile to release all his marital rights in her land located in Massachusetts. Because. the contract was construed to be "personal" rather than one affecting property interests, a Massachusetts court applied North Carolina law validating the agreement rather than Massachusetts law which would have invalidated any husband-wife contract. ${ }^{\circ}$ In the recent case of Kyle $v$. $K y l e, 10$ the court applied situs law to reach a contrary result on similar facts. An antenuptial contract releasing dower rights-valid in the domicile where made but invalid in the situs-forum-was held to have a "direct relationship" to the property in the forum even though the property was acquired several years after the contract. There is a danger that such use of either-or characterization in choice of law may mask the insubstantiality of a forum's contacts with a transaction.

There is also a risk that the determination whether a contract affects interests in land or personal rights may turn on merely the remedy sought. In two leading cases, Selover, Bates \& Co. v. Walsh ${ }^{11}$ and Kryger $v$. Wilson, ${ }^{12}$ the issue was whether there was proper notice of termination of a contract to convey land in one state made and to be performed in another. In Selover, because the action was for damages for breach of

6 Restatement (Second), Conflict of Laws, Introductory Note, at 13 (Tent. Draft No. 5, 1959). See generally Goodrich, Two States and Real Estate, 89 U. PA. L. REv. 417, 418-19 (1941).

7 See Selover, Bates \& Co. v. Walsh, 226 U.S. 112 (1912).

8167 Mass. 211, 45 N.E. 737 (1897) (Holmes, J.).

Id. at $214-15,45$ N.E. at 738.

10128 So. 2d 427 (Fla. Dist. Ct. App. 1961), appeal dismissed, 139 So. 2d 885 (Fla. 1962).

11226 U.S. 112 (1912).

12242 U.S. 171 (1916). 
contract, the forum applied its own law as the law of the place of contracting. ${ }^{13}$ In $K r y g e r$, because the action was to quiet title, the situs-forum applied its own law rather than the law of the state of the parties' domicile and the making and performance of the contract. ${ }^{34}$ The Supreme Court affirmed both cases, noting in Kryger that choice of law is a matter of local common law. ${ }^{15}$ Since the Court in Kryger expressly recognized that the crucial issue concerned the required notice of termination, ${ }^{18}$ the states' conflicting interests in having their notice requirements applied should have been analyzed. Although notice of termination might seem to involve personal rights, the case was held to involve interests in land since the remedy sought was quieting title. Characterization should not be the sole determinant of choice of law when a case falls readily into either category. Indeed, characterization conceals the underlying issues of a conflicts case by furnishing an apparently neat and logical solution without providing any ready-made tools of analysis. Often it serves as a device for the application of forum law.

\section{Defects in the Restatement's Rationale for an Expanded Situs RULE}

The basic problem in choice of law governing immovables concerns the weight to be accorded the situs contact. ${ }^{17}$ It is universally agreed that situs law should govern conveyances. ${ }^{18}$ The most recent draft of the Restatement of Confict of Laws has departed from existing law by making situs also determinative of choice of law in most cases involving contracts to convey. ${ }^{19}$ Although the Restatement appears to be following the contractconveyance dichotomy by framing a special rule for contracts to convey, it undercuts the classical dichotomy by giving such weight to the situs contact that the local law of the situs will almost always govern. ${ }^{20}$ Yet, when the purposes of local laws are examined and applied in specific factual contexts, situs may become a relatively insignificant contact in relation to a contract-to-convey issue.

13109 Minn. 136, 123 N.W. 291 (1909), aff'd, 226 U.S. 112 (1912).

1429 N.D. 28, 149 N.W. 721 (1914), aff'd, 242 U.S. 171 (1916).

15242 U.S. 171, 176 (1916).

16 Ibid.

17 Compare Goodrich, supra note 6, with Restatement (Second), Conflict of LAws $\$ 346$ (e) (Tent. Draft No. 6, 1960).

18 E.g., Goodrich, Conflict of Laws $\$ 148$ (3d ed. 1949); Leflar, Conflict of LAws \& 140 (1959); StuMrerg, CoNfLict of Laws 377 (2d ed. 1951). 1960).

19 Restatement (Second), Conflict of Laws $\$ 346$ (e) (Tent. Draft No. 6,

20 See id. $\$ 346(\mathrm{e})$, comment $c$ \& illustrations 3-6. Reference to the local law of the situs differs significantly from reference to whatever law the situs applies, including possible use of renvoi. Compare id. $\$ 346(\mathrm{e})$, comment $d$ and $\S 332$, comment $e$ (Tent. Draft No. 6, 1960), with Restatement (SECOND), Conflict of Laws $\S 215$, comment $b$ and $\S \S 215-21$ (Tent. Draft No. 5,1959 ). Reference to the whole law of the situs furnishes no guidance as to the local law the situs should apply. $C f$. Cavers, The Conditional Seller's Remedies and the Choice-of-Law Process-Some Notes on Shanahan, 35 N.Y.U.L. REv. 1126, 1135-36 (1960). 
The Restatement's expanded situs rule rests on the theory that land is subject only to the jurisdiction of the courts of the state in which it is situated. ${ }^{21}$ Courts have often found a nexus between jurisdiction and choice of law in land transactions, possibly because it might be futile for a non-situs forum to apply its law and decree that land in another state be conveyed if enforcement of the decree would require further legal action in the situs state whose law voids the conveyance. ${ }^{22}$ However, a collectible money judgment can be as effective a means "for a non-situs court to affect interests in land as a decree for specific performance. ${ }^{23}$ Moreover, situs courts usually acknowledge the validity of a deed given in compliance with a non-situs decree when the grantor seeks to have the deed declared void on the ground of duress. ${ }^{24}$ Perhaps situs courts should, therefore, grant specific performance pursuant to a foreign decree since there is no greater intrusion on a state's control over land when a foreign decree is given effect than when a deed in compliance with such a decree is given effect. ${ }^{25}$ Courts have long been willing to decree that foreign land be conveyed, ${ }^{26}$ and expanding concepts of jurisdiction and full faith and credit have increasingly motivated situs courts to effectuate such decrees. ${ }^{27}$ According to a succession of commentators, foreign land decrees based on personal jurisdiction are entitled to full faith and credit. ${ }^{28}$ Thus, there . seems to be little support for the Restatement's view that the situs has "exclusive control" over land. ${ }^{29}$

21 Restatement (Second), Conflict of Laws, Introductory Note, at 13 (Tent. Draft No. 5, 1959) ; 2 BeAle, Conflict of LAwS \$214.1, at 938-39 (1935).

22 Losson v. Blodgett, 1 Cal. App. 2d 13, 36 P.2d 147 (Dist. Ct. App. 1934); Polson v. Stewart, 167 Mass. 211, 214-15, 45 N.E. 737, 738 (1897) (dictum).

23 Currie, Full Faith and Credit to Foreign Land Decrees, 21 U. CHI. L. Rev. 620, 669-70 (1954); Note, Choice of Law for Land Transactions, 38 ColUM. L. REv. 1049,1051 (1938).

24 See Currie, supra note 23 , at 628-29.

25 Id. at 629 .

26 See, e.g., Penn v. Lord Baltimore, 1 Ves. Sr. 444, 27 Eng. Rep. 1132 (Ch. 1750). Such a decree may be based on defendant's wrong within the forum. E.g.; Irving Trust Co. v. Maryland Cas. Co., 83 F.2d 168, 172 (2d Cir.), cert. dcnied, 299 U.S. 571 (1936); Lord Cranstown v. Johnston, 3 Ves. Jr. 170, 30 Eng. Rep. 952 (1796).

${ }_{27}$ Simmons v. Superior Court, 96 Cal. App. 2d 119, 128, 214 P.2d 844, 851 (Dist. Ct. App. 1950); Redwood Investment Co. v. Exley, 64 Cal. App. 455, 221 Pac. 973 (1923) ; Matson v. Matson, 186 Iowa 607, 173 N.W. 127 (1919); Mallette v. Scheerer, 164 Wis. 415, 160 N.W. 182 (1916). But see, e.g., McRary v. McRary, 228 N.C. 714, 47 S.E.2d 27 (1948); Clouse v. Clouse, 185 Tenn. 666, 207 S.W.2d 576 (1948).

28 Barbour, The Extra-Territorial Effect of the Equitable Decree, 17 Micr. L. Rev. 527 (1919); Currie, Full Faith and Credit to Foreign Land Decrees, 21 U. CII. L. REv. 620 (1954); Goodrich, Enforcement of a Forcign Equitable Decree, 5 Iows L. BuLl. 230 (1920); Lorenzen, Application of Full Faith and Credit Clause to Equitable Decrees for the Conveyance of Foreign Land, 34 YALE L.J. 591 (1925). The issue has not yet been determined by the Supreme Court. The narrow holding of Fall v. Eastin, 215 U.S. 1 (1909), is that full faith and credit need not be given a prior judgment determining rights in land when the present suit concerns rights of a grantee of one of the former parties. See generally Goodrich, Two States and Real Estate, 89 U. PA. L. REv. 417, 428 n. 50 (1941).

29 Restatement (SECOND), Conflict of Laws, Introductory Note, at 12 (Tent. Draft No. 5, 1959). It was recognized over twenty years ago that choice of law concerning immovables should not be based on concepts of jurisdiction. Goodrich, supra note 28 , at $419 \mathrm{n} .12$; Note, sipra note 23 , at 1051 . 
Situs is also stressed by the Restatement on the theory that inmovables are of greatest concern to the state in which they are situated. A1though there may be a legitimate and substantial situs concern when the issue is the direct effect of a conveyance on title, ${ }^{30}$ if it is clear that a case directly involves only personal rights, ${ }^{31}$ the interest of a state in regulating the rights of its domiciliaries may outweigh the interest of the situs state in regulating immovables.

Finally, the Restatement has given greatest weight to the situs contact to satisfy the need for certainty and convenience ${ }^{32}$ - it is far easier to determine in what state land is situated than to determine the place of contracting. The Restatement's rationale is persuasive when the issue involves title since certainty in the effect of prior conveyances is essential in establishing a chain of title. But when title is not directly involved, it may be preferable to sacrifice certainty in a search for the proper law of a particular case-the law of the state having the most significant contacts with the transaction and the greatest interest in having its law applied to the specific facts. Furthermore, a rule requiring ineluctable application of situs law cannot provide predictability in all cases because many courts, recognizing that a non-situs state has more significant contacts, have refused to apply the rule uniformly. ${ }^{33}$

\section{Weighing of Contacts: Contracts to Convey}

Most courts have held that issues related to the contract to convey are governed by the law normally applied to contracts. ${ }^{34}$ Occasionally, courts have indicated that every issue concerning an immovable is governed by the law of the situs; ${ }^{35}$ but in some of the cases, situs law has been applied to a contract to convey when that same law would also have been chosen under the jurisdiction's contract rule. ${ }^{36}$ The Restatement provides that when the parties are separately domiciled, the law of the situs is applied even if execution of the contract to convey, delivery of the deed, and payment are non-situs contacts. ${ }^{37}$ Giving such weight to the

30 See pp. 490, 495 infra.

31 See, e.g., pp. 492-93 infra, on assumption of a mortgage.

32 Restatement (Second), Conflict of Laws, Introductory Note, at 13 (Tent. Draft No. 5, 1959).

33 E.g., Liljedahl v. Glassgow, 190 Iowa 827, 180 N.W. 870 (1921) (assumption of mortga governed by law of place where agreement was executed and was to be of mortgage governed balker, 179 Mass. 514, 61 N.E. 58 (1901) (damages when vendor unable to furnish good title governed by law of place of contracting); Polson V. Stewart, 167 Mass. 211, 45 N.E. 737 (1897) (wife's capacity to contract with husband governed by law of domicile of spouses and place of contracting); Walsh $v$. Selover, Bates \& Co., 109 Minn. 136, 123 N.W. 291 (1909), aff'd, 226 U.S. 112 (1912) (termination of contract of sale governed by law of place of making and performing contract).

34 See cases cited note 33 supra.

35 See, e.g., Coral Gables, Inc. v. Hanley, 87 F.2d 780 (6th Cir. 1937).

3 B See, e.g., Hamilton v. Glassell, 57 F.2d 1032 (5th Cir. 1932) (dictum).

37 RestateMENT (SECOND), CONFLICT of LAws $\$ 346(\mathrm{e})$, comment $c$, illustration 6 (Tent. Draft No. 6, 1960). 
situs can only be justified as a means of securing uniformity and predictability; however, courts are unlikely to deviate from the traditional rule which requires application of the law of the state having the contacts of execution, delivery, and payment. ${ }^{38}$ Moreover, the state in which performance is to occur normally has the greatest interest in regulating the effect of non-performance within its borders. ${ }^{39}$ The situs state's interest in regulating title is not involved since the contract is breached before there is any conveyance affecting title.

Courts too often ignore the contact of domicile, a failing which is especially unfortunate when a pertinent state statute was specifically designed to protect domiciliaries rather than to regulate transactions. ${ }^{40}$ For example, a statute providing a period within which to comply with a contract to convey before it can be terminated may indicate a state interest in protecting domiciliaries. ${ }^{41}$ In Kryger $v$. Wilson, ${ }^{42}$ the situs forum applied local law because the remedy sought was quieting title. The Court's express recognition that the crucial issue involved the required notice of termination ${ }^{43}$ indicated the need for analysis of the states' interests in having their notice requirements applied. ${ }^{44}$ Not only was the purchaser domiciled in the non-situs state which had a notice of termination requirement affording greater protection, ${ }^{\mathbf{4 5}}$ but the contract was made and was to be performed within that state. The situs state's interest in quieting title need not compel application of situs law since title is quieted no

38 See cases cited note 33 supra.

39 The state in which the deed is to be delivered and installments are to be paid has an interest in seeing that the contract is carried out and in regulating the consequences of a willful breach. Frequently the state of performance and the state of making the contract are the same. When they are not, the contact of performance probably should be given the greater weight. Courts following the early rule that the place of making governs contracts, frequently apply the law of a state having little interest in regulating the contract. See, e.g., Milliken v. Pratt, 125 Mass. 374 (1878). See generally Currie, Married Women's Contracts: A Study in Conflict-of-Laws Method, 25 U. CHI. L. REv. 227, 235 (1958). More recently, courts applying "the law of the contract" may have meant the law of the place of performance instead of the law of the place of making. That the quoted phrase may have either or both meanings was pointed out in Pritchard v. Norton, 106 U.S. 124, 136 (1882) (dictum).

40 When a breach by a vendor domiciled in the situs state is caused not by an unwillingness to convey but by an inability resulting from a defect in title, the situs state has a significant interest in protecting the local vendor who in good faith made a contract to convey believing that he had good title. The vendor is most likely to be a domiciliary of the state in which his land is situated. But if he is domiciled in the state of performance, that state has an interest in protecting him by a good faith rule of nominal damages and expenses instead of profits lost. In a leading case, Atwood v. Walker, 179 Mass. 514, 61 N.E. 58 (1901), the situs forum applied the nominal damages rule of New York, in which the contract was made and the deed was to be delivered, without considering whether the vendor was a domiciliary of Massachusetts. If he was and his home state did not protect him, there would seem to be no reason why its court should have applied New York law protecting vendors.

41 See Selover, Bates \& Co. v. Walsh, 226 U.S. 112 (1912).

42242 U.S. 171 (1916).

43 Id. at 174.

44 See text accompanying note 16 supra.

45 Both statutes required written notice of termination and thirty days within which to perform after receiving notice, but only the situs state permitted notice by publication. See Kryger v. Wilson, 242 U.S. 171 (1916). 
matter which statute is applied. Even the Restatement does not require that situs law be applied when situs is the state's only contact with the contract. ${ }^{46}$

\section{A. Capacity to Contract 47}

At one time a court would apply a local statute or conmon-law rule providing that married women were incapable of making valid conveyances without considering whether it was intended to apply to the particular facts in issue. ${ }^{48}$ In Proctor v. Frost, ${ }^{49}$ however, a situs court of State $X$ recognized that a local statute voiding a married woman's mortgage of her land as surety for her husband's debt was designed to protect only local domiciliaries; ${ }^{\text {so }}$ therefore, the court applied the law of State $Y$ in which the mortgagor was domiciled, had executed the bond and mortgage, and was competent. ${ }^{11}$ Actually, there was no true conflict in the case; since the forum had no interest in protecting a non-domiciliary, ${ }^{52}$ the interest of State $Y$ in upholding the contract could be freely effectuated. ${ }^{53}$

When the married woman is domiciled in $X$, however, and State $Y$ has some significant contact with the contract, there is a real conflict between $X$ law which seeks to protect the wife and $Y$ law which enforces such a contract. Although state legislators, who are normally concerned with purely local transactions, ${ }^{5 ;}$ probably envisioned the $X$ statute as applicable only when all relevant contacts-domicile, place of making or performing the contract, and situs-were within $X$, an $X$ forum can be expected to apply the statute even if one contact, the making or performance, was in $Y .^{\mathbf{5 5}}$ The policy underlying a statute voiding a married woman's mortgage of her land as surety for her husband's debt is to

46 Restatearent (Second), Conflict of Laws $\$ 346(e)$, comment $c$ \& illustration 2 (Tent. Draft No. 6, 1960).

47 Although this subject now has little practical significance due to the removal by most states of restrictions on the capacity of married women to contract, treatment is justified if it can aid current classroom discussion of capacity as a problem in choice-of-law method. Detachment from controversial local policy perhaps facilitates analysis of method. Currie, supra note 39 , at 227-28.

48 See, e.g., Swank v. Hufnagle, 111 Ind. 453, 13 N.E. 105 (1887); Smith v. Ingram, 130 N.C. 100,40 S.E. 984 (1902).

4989 N.H. 304,197 Atl. 813 (1938).

so See id. at 307-08, 197 Atl. at 815.

51 Accord, Polson v. Stewart, 167 Mass. 211, 45 N.E. 737 (1897) ; Merrielles v. State Bank, 5 Tex. Civ. App. 483, 24 S.W. 564 (1893).

52 See 89 N.H. 304, 307-08, 197 Atl. 813, 815 (1938).

53 Cf. Currie, supra note 39 , at 260-61.

54 Bernkrant v. Fowler, 55 Cal. 2d 588, 594, 360 P.2d 906, 909, 12 Cal. Rptr. 266,269 (1961) (dictum); Currie, stipra note 39, at 230-31.

55 The court could argue that the interest of the forum state in protecting domiciliaries is as great as that in Emery v. Burbank, 163 Mass, 326, 39 N.E. 1026 (1895), in which a court applied the local statute of frauds to prevent a local testator from being bound by an alleged oral contract made elsewhere. Accord, Bernikrant v. Fowler, $55 \mathrm{Cal}$. 2d 588. 594. 360 P.2d 906, 909, 12 Cal. Rptr. 266, 269 (1961) (dictum); Rubin v. Irving Trust Co., 305 N.Y. 288, 113 N.E.2d 424 (1953). However, $Y$ courts have enforced married women's contracts valid where made (in $Y$ ) although invalid in the domicile $(X)$. See, e.g., Conner v. Elliott, 79 Fla. 513, 85 So. 164, petition for cert. dismissed, 254 U.S. 665 (1920). 
foster domestic tranquility by ensuring that a husband will not force his wife to make a contract benefiting him, and the spouses' domicile has the greatest interest in promoting marital harmony. On the other hand, if the deed is to be delivered in $Y$, payments are to be made there, and the other party is domiciled there, $Y$ has both a protective interest and an interest in upholding a contract to be performed within its borders. In such a case, the contacts and interests of the two states are evenly balanced. In practice, a party seeking to hold a married woman to her contract will sue in $Y$ whose law validates the contract, provided that personal jurisdiction can be obtained over the $X$ domiciliary. The $Y$ forum probably will apply $Y$ law on the basis of its contacts, interests, and the presumption that the $X$ domiciliary intended to make a binding contract rather than to deceive and thus would have intended $Y$ law to govern had she considered the conflict-of-laws problem.56 Although enforcement of all contracts on the ground of upholding the expectation of the parties would undercut $X$ 's policy of protecting married women and maintaining domestic tranquility, the use of presumed intent has been supported by many writers. ${ }^{57}$ Choice-of-law rules can provide no easy solution here.58 Yet by eschewing the contract-conveyance dichotomy and considering the purposes and scope of local laws in order to weigh interests and contacts, courts can at least ensure that relevant but conflicting policies will not be overlooked.

If the situs as well as the place of contracting is in $Y$, it is possible that the $X$ statute was not intended to apply.59 Of course, if plaintiff must sue in $X$ because personal jurisdiction over the $X$ domiciliary cannot be obtained in $Y$, the $X$ court may well hold that $X$ 's policy of protecting domiciliaries is strong enough to compel application of $X$ law even though domicile is $X$ 's only contact. ${ }^{60}$ This approach by the forum has been roundly criticised, ${ }^{61}$ mainly because of $Y$ 's significant interest in upholding a contract which the parties presumably intended to be valid. But $Y$ 's interest is not significantly stronger than in the preceding hypothetical if the situs contact is not deemed crucial in this area. The argument that the situs has an interest in the uniform application of situs law to ensure certainty of titles to local land is not compelling here, for legal title is not affected until

58 See, e.g., Poole v. Perkins, 126 Va. 331, 101 S.E. 240 (1919).

57 Ehrenzweig, Contractual Capacity of Married Women and Infants in the Confict of Laws, 43 MiN N. L. REv. 899, 901 (1959); Williams, Land Contracts in the Conflict of Lazes-Lex Situs: Rule or Exception, 11 HAsmngs L.J. 159, 168 (1959); Note, Choice of Law for Land Transactions, 38 Coluar. I. REv. 1049, 1055 (1938).

58 Professor Currie suggests that in such a case each forum should effectuate local policy. Currie, supra note 39 , at 261-62.

59 See note 54 supra and accompanying text. Cf. Poole v. Perkins, $126 \mathrm{Va} .331$, 333, 101 S.E.2d 240, 242 (1919) (dictum) (lack of capacity to contract under law of domicile not applicable when contract made in another state).

$60 \mathrm{Cf}$. cases cited note 55 supra. Professor Currie would approve $X$ 's action. See Currie, stipra note 39, at 261-62.

61 Cf., e.g., Ehrenzweig, The Statute of Frauds in the Conflict of Lazes: Basic Rule of V alidation, 59 CoLUs. L. REv. 874, 880 (1959); Iorenzen, The Statute of Frauds and the Conflict of Lazes, 32 Y ALE L.J. 311, 335-37 (1923); Comment, The Statute of Frauds in the Conflict of Laws, 43 CALIF. L. REv. 295, 302, 304 (1955). 
there is a conveyance subsequent to the contract to convey. ${ }^{62}$ Moreover, since many courts, following the dichotomy, now apply the law of the place of contracting, pre-litigation certainty can be assured by continued application of that law. If suit on the contract is brought, there will be no uncertainty of title regardless of the result since only one party will be awarded the right to the land. If $X$ upholds the contract to convey and the grantor refuses to comply, there may be post-litigation uncertainty, but only until $Y$ decides whether to follow persuasive authority for enforcing the foreign decree. ${ }^{63}$

\section{B. Capacity to Convey ${ }^{84}$}

The issue of capacity to convey, rather than to contract to convey, requires greater emphasis on the situs contact since the situs state has a significant interest in regulating conveyances directly affecting title to local land. Title searching is facilitated if the situs law pertaining to capacity to convey is applied to all conveyances. Since deeds are recorded near the situs, title searches are commonly made by lawyers most familiar with situs law. The lack of a definite conflict-of-laws rule detracts from certainty of title, for the possibility of error is increased when the law of sereral states need be considered in order to ascertain whether all parties in a chain of conveyances had capacity to convey. A non-situs state's interest based on delivery of the deed within its borders is usually entitled to less weight-delivery is frequently a fortuitous contact determined by factors, such as the location of a broker's office, which are not relevant to the choice-of-law issue.

If a married woman is domiciled in the situs state, $X$, and the parties are sufficiently advised to have settlement in $Y$ whose law validates the conveyance, they should also append a clause designating $Y$ law to govern the conveyance, and this designation should be implemented. If a married woman is domiciled in $X$, and $X$ law upholds the conveyance whereas $Y$ law invalidates it, $X$ law should be applied regardless of the situs since there is no conflict- $Y$ has no interest in protecting a non-domiciliary ${ }^{65}$ and $X$ law makes it possible to uphold the conveyance. If the situs was in $Y$, although $Y$ might have an interest in having its law applied to facilitate title searches, this interest should be subordinated to the larger policy of effectuating transfers of land. ${ }^{6 B}$ The desire for certainty which

62 Although a purchaser under a contract for sale has an equitable right to the land, he may not choose to enforce his action for specific performance or specific periormance with abatement after a breach by a vendor. Since only the capacity to contract of the current parties is relevant, there is no need to consider the convenience of applying only one law, presumably that of the situs, to determine whether other parties in the chain of title had capacity. Whether or not prior contracts culminated in conveyances, they have no relevance in subsequent transactions.

63 See authorities cited notes $27-28$ supra.

64 Sea note 47 supra.

65 See notes $49-53$ supra and accompanying text.

66 See generally authorities cited note 57 supra. 
would obviate litigation should not override the application of the law of the state having the most significant interest in having its law applied to the particular case.

Reversing the statutes again so that $X$ law invalidates the contract whereas $Y$ law upholds it, if the married woman's domicile remains in $X$ but situs is in $Y$, situs now becomes a significant contact. Interests which previously conflicted, such as the need for certainty of title, facilitating title searches, and upholding the validity of conveyances, all combine now in $Y$ to point to the application of $Y$ law. $X$ 's interest in protecting its domiciliary seems to be outweighed.

\section{The Statute of Frauds}

Some courts have applied the situs statute of frauds to all contracts to convey because land was involved. ${ }^{67}$ However, whether a particular statute of frauds is applied to an oral contract to convey more often depends on whether the statute is construed as procedural-and thus applicable only to suits within the state of enactment-or substantive-and applicable outside the state. ${ }^{68}$ Indeed, in this area, the situs contact is irrelevant. If the primary purpose of a statute is to prevent the imposition of fraudulent evidence on the local courts, it should be considered procedural; but if a statute is designed to protect contracting parties from fraud, it is substantive and can be effective only if applied wherever suit is brought. ${ }^{69}$

Many courts have applied whichever law-situs or contract-validated the contract on the ground that the parties presumably intended that law to apply since they meant to make a valid contract. ${ }^{70}$ In considering the presumed intent of the parties, one court ${ }^{71}$ noted that the situs statute should govern, but that it was procedural and therefore applicable only within the situs state; the court then applied its own statute which it also construed as procedural. ${ }^{72}$ Had the court construed its statute as substantive, it would have been compelled to uphold an oral contract simply because neither the substantive statute of the forum nor the procedural statute of the situs state was applicable. ${ }^{73}$ This awkward situation could be avoided if all statutes were construed as substantive or procedural. Perhaps the policy of procedural statutes-protecting courts from fraud, perjury, and tedious litigation by prohibiting suit on an oral contractshould be subordinated to the substantive statutory policy of protecting

67 E.g., Cochran v. Ward, 5 Ind. App. 89, 29 N.E. 795 (1892) ; Meylink v. Rhea, 123 Iowa 310,98 N.W. 779 (1904).

68 See, e.g., Lams v. F. H. Smith Co., 36 Del. 477, 178 Atl. 651 (Super. Ct. 1935); Halloran v. Jacob Schmidt Brewing Co., 137 Minn. 141, 147, 162 N.W. 1082, 1084 (1917).

89 Lams v. F. H. Smith Co., supra note 68.

70 See Ehrenzweig, The Statute of Frauds in the Conflict of Laws: Basic Rules of Validation, 59 CotuM. L. REv. 874 (1959).

71 Hamilton v. Glassell, 57 F.2d 1032 (5th Cir. 1932).

72 See id. at 1034.

73 See Marie v. Garrison, 13 Abb. N. Cas. 210 (N.Y. 1883). 
domiciliaries from forced compliance with contracts they never made, so that all statutes of frauds would be construed as substantive. ${ }^{74}$ In fact, it is generally accepted that statutes of frauds do not prevent fraud in courts. ${ }^{75}$

Since there is little variation among the state statutes which would indicate a substantial difference in policy, ${ }^{76}$ the best solution may be to apply whichever statute would validate the contract. A similar "alternative reference rule" is applied in the area of usury statutes in which the difference in the maxinum rate of permissible interest from state to state is not based on substantial policy distinctions.77 By applying whichever statute validates the contract, the presumed intent of the parties to make a valid contract is effectuated. ${ }^{78}$

\section{Weighing of Contacts: Mortgages}

During the period in which many states limited the capacity of married women to mortgage land, mechanistic application of the contractconveyance dichotomy often rendered mortgages worthless. When a note and mortgage were executed in a state in which the mortgagor lacked capacity, although she was competent under situs law, the mortgage was usually upheld as involving a property interest and thus governed by situs law, whereas the note was invalidated as a mere contract governed by the law of the place of contracting. ${ }^{79}$ If, according to situs law, a valid note was required to support a mortgage, the otherwise valid mortgage would fail. Application of the contract-conveyance dichotomy was unwarranted because the situs statute probably was intended to require only that the note be valid under local situs law.

The contract-conveyance dichotomy does, however, furnish appropriate guidelines in certain mortgage cases in which the rights and obligations involved do not directly affect title to land. When a mortgagor conveys his interest in land, the general rule is that the law of the place of execution and performance governs the issue of whether the grantee assumed the obligation to satisfy the mortgage. ${ }^{80}$ In the leading case of Liljedahl v. Glassgow, ${ }^{81}$ a grantee of mortgaged land did not sign his name in the blank provided in a deed which had an express assumption

74 See cases cited note 68 supra.

75 See, e.g., Lams v. F. H. Smith Co., 36 Del. 477, 483, 178 At1. 651, 653 (Super.

C. 1935) ; Lorenzen, supra note 61, at 334-38.

${ }^{76}$ See, e.g., Halloran v. Jacob Schmidt Brewing Co., 137 Minn. 141, 147-48, 162

N.W. 1082, 1084 (1917). See generally Ehrenzweig, sipra note 70, at 880 .

77 See, e.g., Mueller v. Ober, 172 Minn. 349, 215 N.W. 781 (1927); Castleman v.

Canal Bank \& Trust Co., 171 Míiss. 291, 156 So. 648 (1934).

78 Cf. GOODRICH, CoNflict of LAws $\$ 88$, at $247-48$ (3d ed. 1949).

79 Conner v. Elliott, 79 Fla. 513, 85 So. 164 , petition for cert. dismissed, 254 U.S.

665 (1920); cf. Thompson v. Kyle, 39 Fla. 582, 23 So. 12 (1897).

80 E.g., Duvall-Percival Trust Co. v. Jenkins, 16 F.2d 223 (8th Cir. 1926);

Liljedahi v. Glassgow, 190 Iowa 827, 180 N.W. 870 (1921); Clement v. Willett, 105

Minn. 267, 117 N.W. 491 (1908).

81190 Iowa 827,180 N.W. 870 (1921). 
clause. The court held that the grantee had assumed under the law of the state of execution and performance since the agreement to pay was a personal covenant, and situs law-under which the grantaee was not liable to the mortgagee-was inapplicable. Most writers agree that the state in which the debt is to be paid has a greater interest in determining who must pay than the state in which the security for the debt happens to be situated. 82

It has also been held that the question of whether a deficiency judgment can be obtained when the amount produced by a foreclosure falls short of the debt is a contractual matter. ${ }^{83}$ Here, however, the interest of a state in protecting local mortgagors should be evaluated by inquiring into the intended reach of statutes prohibiting deficiency judgments or limiting recovery to the difference between the debt and the actual value of the land rather than the proceeds of sale. Thus, in McGirl v. Brezer, ${ }^{54}$ the forum did not apply its statute to protect a local mortgagor since it held the statute inapplicable to a mortgagor who executed a mortgage in another state on land within that state, implying that domicile alone was an insufficient contact. The court refused to apply forum law on any basis of procedure or local public policy, ${ }^{85}$ nor was it even convinced of the substantiality of the policy of protecting local mortgagors since a direct suit on the note, which would achieve the same purpose as a deficiency judgment, was not barred. ${ }^{86}$ In similar cases, some courts, in order to protect local mortgagors, have justified the application of forum law on grounds of procedure ${ }^{87}$ or public policy, ${ }^{88}$ even though most of the contacts were in other states. Such use of the public policy doctrine ${ }^{89}$ obfuscates the issue of legislative purpose which the court in McGirl $v$. Brewer met head-on.

When the situs and place of contracting are in different states, there is even greater need for considering the scope of particular statutes to ascertain, for example, if a statute restricting deficiency judgments was intended to protect local mortgagors only when they mortgaged local

82 See Goodrich, Conflict of Laws $\$ 149$ (3d ed. 1949); Leflar, Conflict of LAws $\$ 144$, at 277 (1959).

83 E.g., Stumpf v. Hallahan, 101 App. Div. 383, 91 N.Y. Supp. 1062 (1905), aff'd, 185 N.Y. 550,77 N.E. 1196 (1906) (question of contract but parties must have intended applicability of law of situs where presumably the debt was payable); Hall v. Hoff, $295 \mathrm{~Pa} .276,145$ Atl. 301 (1929) (place of execution governed).

84132 Ore. 422, $280 \mathrm{Pac} 508$ (1929), affirmance upheld on rehearing, 132 Ore. 432, 285 Pac. 208 (1930).

85 Ibid.

86 Id. at 436-37, $285 \mathrm{Pac}$ at 208. See generally Currie \& Lieberman, PurchaseMoney Mortgages and State Lines: $A$ Study in Conflict-of-Laws Method, 1960 DurE L.J. 1, 21-22.

87 E.g., Bullington v. Angel, 220 N.C. 18, 16 S.E.2d 411 (1941).

88 E.g., Federal Deposit Ins. Corp. v. Stensland, 70 S.D. 103, 107, 15 N.W.2d 8, 10 (1944).

89 Currie \& Lieberman, supra note 86, at 50, citing Watson v. Employers Liab. Assur. Corp., 348 U.S. 66 (1954), and Alaska Packers Ass'n v. Industrial Acc. Comm'n, 294 U.S. 532 (1935). 
land. ${ }^{00}$ If a mortgagor resides in the situs state which prohibits or restricts deficiency judgments, and such a judgment is sought in the state where the mortgage was made and to be paid, which permits such judgments, contacts and interests seem to be evenly balanced until the nature and purpose of the anti-deficiency judgment statute are considered. In addition to the usual interest in protecting its residents, the situs state has an interest in assuring other creditors of the mortgagor, who are likely to live near the mortgagor in the situs state, a fair share of his assets on default. Uniike the contract-to-convey cases in which the state of performance has an interest in upholding the parties' expectations of making a binding contract, it cannot be said that the state in which a mortgage is to be satisfied has an interest in upholding the parties' expectations since the parties probably did not foresee that the value of the land as security might not be equal to the debt at some future date. Goodrich, too, would tip the scales in favor of situs law, but on the somewhat tenuous ground that the mortgagee, having obtained foreclosure in the situs, should be held to have submitted disposition of his entire claim to the situs courts.91 On the other hand, the Restatement argues that a mortgagee's right to collect a deficiency should be governed by the law of the place of the underlying debt since title to land is not affected and since all collateral foreclosure matters should be governed by a single law. ${ }^{92}$ Nevertheless, although title is not affected, the domicile-situs does have an interest in protecting a local mortgagor which seems to outweigh the convenience of applying only one law to the transaction, particularly when there is no interest in upholding the expectations of the parties.

\section{Weighing of Contacts: Legal Effect and Construction of Conveyances}

The Restatement ${ }^{93}$ provides that situs law governs not only when state statutes, in implementing local public policy, require that certain words in a conveyance have a definite legal effect regardless of the meaning intended by the parties, ${ }^{94}$ but also when, in the absence of such statutes or satisfactory evidence of intent, ${ }^{95}$ a conveyance must be con-

90 See Hall v. Hoff, $295 \mathrm{~Pa}$. 276, 145 Atl. 301 (1929).

91 Goodrich, CoNFLict of LAws $\$ 152$, at 469 \& n.68 (3d ed. 1949). Of course, if the issue is merely what steps must be taken in order to recover a deficiency, the question is procedural. Cf. Belmont v. Cornen, 48 Conn. 338 (1880) (recovering deficiency without court action governed by forum law).

92 Restatement (SeCoNo), Conflict of Laws $\$ 227$, comment $d$ \& Reporter's Note (Tent. Draft No. 5, 1959).

93 Restatement (SecoND), Conflict of Laws \$214 (Tent. Draft No. 5, 1959).

94 Id. $\S 214$, comment $b$.

95 If such evidence is presented, the intent of the parties will normally be effectuated. See $i d$. $\$ 214$, comment $c$. The Restatement distinguishes between interpretation - construing words in accordance with the intent of the parties established by satisfactory evidence-and construction-construing words in accordance with a presumption in the absence of sufficient evidence of intent. Id. $\$ 214$, comments $a, c$, d. 
strued by applying a presumption normally based on probable intent. ${ }^{98}$ That situs law should be determinative of the legal effect of words in a conveyance seems justified in terms of the interest of the situs state in obtaining uniformity and certainty of titles to land within its borders. If, for example, $A$ conveys to $B$ for life, then to his heirs, the legal effect of these words would vary significantly if differing statutes modifying or overruling the Rule in Shelley's Case were applicable rather than just onethe situs statute. Also, title searches, usually made in the situs state where deeds are recorded, would be even more onerous than at present if the laws of the various states in which past grantors were domiciled rather than just situs law had to be consulted.97

When the issue is construction of a conveyance rather than its legal effect, the interest in facilitating title searches through the application of a single situs law carries little weight. Although a title searcher can rely on a statute which determines legal effect regardless of the intention of the parties, he cannot so rely on a rule of construction which can be overcome by evidence of a contrary intent. ${ }^{98}$ In addition, a legal-effect issue commonly concerns future interests or the rights and duties of life tenants and remaindermen, and since lawyers tend to think of the relevant real property law in territorial terms, ${ }^{99}$ it seems appropriate that situs law should apply. Rules of construction, however, 'often appear to be no more closely related to property than to the parties. ${ }^{100}$ And in contrast to legal-effect rules which, by disregarding intent, evidence a strong state policy, many rules of construction are arbitrary-based not even on probable intent. Therefore, the Restatement may have overemphasized the importance of situs in relation to construction of conveyances. ${ }^{101}$

At one point, however, the Restatement does approach the problem by considering specific factual situations, noting that many courts distinguish between conveyances supported by consideration and gift conveyances on the ground that when a gift is made only the donor's intent is relevant. ${ }^{102}$ For gift conveyances, the Restatement urges that the construction common in the grantor's domicile be applied-a person normally speaks the language of his home, and unless the construction of

96 Restatement (Second), Conflict of Laws $\$ 214$, comment $d$ (Tent. Draft No. 5, 1959).

97 See generally Goodrich, Tzeo States and Real Estate, 89 U. PA. L. REv. 417, 419 (1941).

98 Restatement (Second), Conflict of Laws \$214, comment $d$ (Tent. Draft No. 5, 1959). See generally Note, Choicc-of-Law Rules for the Construction and Interpretation of Written Instrumcnts, 72 HARv. L. REv. 1154, 1160 (1959).

99 See generally Goodrich, supra note 97, at 419 .

100 Note, supra note 98 , at 1159.

101 Accord, Peet v. Peet, 229 Ill. 341, 82 N.E. 376 (1907) ; Jennings v. Jennings, 21 Ohio St. 56 (1871). Contra, Greenwood v. Page, 138 F.2d' 921 (D.C. Cir. 1943); Rose v. Rambo, 120 Miss. 305,82 So. 149 (1919).

102 Restatearent (Second), Conflict of Laws $\$ 214$, comment $d$ (Tent. Draft No. 5,1959$)$. 
his domicile is applied, words in a single instrument conveying land in several states could be construed to have varying meanings. ${ }^{103}$ Although the construction of the grantor's domicile might be applied in all situations, ${ }^{10 *}$ better results are more likely to be obtained when that state's rule which is based on the probable intent of the parties is applied. If both state rules have a rational basis, the law of the grantor's domicile should prevail since presumably it is more likely to represent probable intent than the situs ruie. If both rules are arbitrary, application of the rule of the grantor's domicile ${ }^{105}$ may afford as reasonable a solution as is possible; at least uniformity of result regardless of forum can be achieved if the choice between two arbitrary rules is always resolved in favor of the grantor's domicile. ${ }^{106}$

\section{Conclusion}

Only by analyzing the significance of a transaction's contacts with various states through a consideration of the purposes of local laws is it possible consistently to select the law of the state having the greatest interest in seeing its law govern the transaction. Neither mechanistic application of the contract-conveyance dichotomy nor complete acceptance of the Restatement's emphasis on situs law seems adequate. The analytical approach urged by this Note seeks not to provide rules of thumb for selected fact situations, but to untangle conflicting policies so as to discover the proper law of a given case.

Susan P. Windle

103 Ibid. The Restatement then indicates that a lawyer may intend that a conveyance be construed in accordance with situs law because of situs control over the land. However, if a lawyer considered problems of future construction, he should have provided that a certain law was intended to govern. Such a provision would be given effect since rules of construction are applied only in the absence of sufficient evidence of intent. See In re Adriance's Estate, 158 Misc. 857, 286 N.Y. Supp. 936 (Surr. Ct. 1936).

104 See generally Note, supra note 98, at 1159-60.

105 See authorities cited notes 103-04 supra.

106 Cf. Restatement (Second), Conflict of Laws $\$ 214$, comment $d$ (Tent. Draft No. 5, 1959), which suggests that whatever rule-that of grantor's domicile or of the situs-situs courts apply to a gift conveyance of land should be applied by other forums. 